\title{
MEASURING MECHANICAL IMPEDANCE IN CLAYEY GRAVELLY SOILS ${ }^{(1)}$
}

\author{
R. STOLF ${ }^{(2)}$,D. K. CASSEL ${ }^{(3)}$, L.D. KING ${ }^{(3)} \&$ K. REICHARDT ${ }^{(4)}$
}

\begin{abstract}
SUMMARY
Mechanical impedance of clayey and gravelly soils is often needed to interpret experimental results from tillage and other field experiments. Its measurement is difficult with manual and hydraulic penetrometers, which often bend or break in such soils. The purpose of this study was to evaluate the feasi bi lity of a hand-operated "Stolf" impact penetrometer to measure mechanical impedance (soil resistance). The research was conducted in Raleigh, North Carolina, USA ( $35^{\circ} 45^{\prime} \mathrm{N}, 7^{\circ} 42^{\prime} \mathrm{W}$, elevation $75 \mathrm{~m}$ ). Corn was planted on April 19, 1991. Penetrometer measurements were taken on May 10, 1991, in $5 \mathrm{~cm}$ intervals to $60 \mathrm{~cm}$ at 33 locations on a transect perpendicular to the corn rows in each of four tillage treatments. The data permitted three-dimensional displays showing how mechanical impedance changed with depth and distance along the transect. The impact penetrometer proved to be a useful tool to collect quantitative mechanical impedance data on "hard" clayey and/or gravelly soils which previously were difficult to reliably quantify.

Index terms: impact penetrometer, soil resistance, hard clayey and gravelly soils, spatial distribution.

\section{RESUMO: MEDIDA DA IMPEDÂNCIA MECÂNICA EM SOLOS ARGILOSOS E PEDREGOSOS}

Freqüentementefaz-senecessária a medida da impedância mecânica em sol os argi losos e pedregosos como dado auxi liar para a interpretação de experimentos de manejo do sol o. Contudo, os penetrômetros convencionais dobram e quebram com freqüência nesses sol os. O objetivo do estudo foi avaliar a possi bilidadeeoperaci onalidadedeutilizar o penetrômetro
\end{abstract}

(1) Received for publication in J anuary of 1996 and aproved in March of 1997. Apoio: Low Input Sustainable Agriculture program of the U.S. Department of Agriculture, the J essie Smith Noyes Foundation, e FAPESP - Fundação de Amparo à Pesquisa do Estado de São Paulo, Brasil.

(2) Professor, Universidade Federal de São Carlos. Caixa Postal 153, CEP 13600-000 Araras (SP).

(3) Professor, Department of Soil Science, North Carolina State University. Box 7619, Raleigh, NC 27696-7619, USA.

(4) Professor, Universidade de São Paulo. Caixa Postal 9, CEP 13418- 970 Piracicaba (SP). 
deimpacto modelo "Stolf" para medir a impedância (resistência do sol o). O experimento foi desenvolvido em Raleigh, Carolina do Norte, EUA ( $35^{\circ} 45^{\prime} \mathrm{N}, 78^{\circ} 42^{\prime} \mathrm{S}$, altitude de $75 \mathrm{~m}$ ). Plantou-se mi lho em 19 deabril de 1991. As medi das de penetrômetro foram realizadas em 10 demaio do mesmo ano, em interval os de $5 \mathrm{~cm}$ atéa profundi dadede $60 \mathrm{~cm}$ em 33 pontos deuma transeção perpendicular às linhas deplantio demil ho, em quatrodiferentes si stemas de manejo. O penetrômetro de impacto revelou-se útil para o levantamento de dados de resistência em sol os argi losos e/ ou pedregosos, em locais previamenteconstatados como de difícil tomada de medidas por métodos convencionais.

Termos de indexação: penetrômetro de impacto, resistência do solo, solos de alta dureza argil osos e pedregosos, distribuição espacial.

\section{INTRODUCTION}

Tillage practices, crop rotations, and green manure crops can havelarge impacts on the physical conditions of soils (Culley et al., 1987; Nesmith et al., 1987). The degree of soil disruption or compaction varies with the kind and frequency of tillage and wheel traffic as well as the soil water content at the time of tillage. Characterization of mechanical impedance is useful to evaluate the effects of tillage systems on soil physical properties (Cassel, 1983) and crop yield (Vepraskas, 1988). Conceptually, the measurement of soil resistance with a cone penetrometer is simple, but the device is difficult to use in "hard" (high soil strength) soils, the very soils which we often wish to characterize.

Manually-operated penetrometers are difficult to push into hard soils and penetrometer shafts often bend or, in extreme cases, break, if the clay content is high or if gravel or rocks are present. The majority of soils in the Piedmont region of the southeastern U.S. and in many areas throughout the world, fall into this category. Hydraulic systems have been used to provide the large force required to push penetrometers into the soil (Cassel et al., 1978), but hydraulically driven penetrometers havelimited use on gravelly soils because the penetrometer shaft often bends when the penetrometer tip encounters gravel.

An impact penetrometer is designed to penetrate the soil in response to repeated impacts of a known mass falling through a known distance (Stolf et al., 1983; Stolf \& Faganello, 1983). This type of penetrometer does not require a greater instantaneous force when the penetrometer tip encounters a hard soil layer, but instead requires only a greater number of impacts. The simplicity of theimpact penetrometer makes it a viablecandidate to measure mechanical impedance on gravelly, high strength Piedmont soils.

The objectives of this study were: 1 ) to determine the feasibility and capability of using an impact penetrometer to assess mechanical impedance in a high-strength soil containing gravel and a high clay content, and 2) to describe and analyze the mechanical impedance patterns for four experimental systems in a sustainableagriculture experiment.

\section{Theory of the impact penetrometer}

The Stolf impact penetrometer and large penetrometers used in civil engineering applications are based on the same principle.

According to Stolf (1991), impact penetrometers (Figure 1) measure the dynamic resistance, R, given by

$$
\mathrm{R}=\mathrm{F} / \mathrm{A}
$$

where $\mathrm{F}$ is the force (newton) and $\mathrm{A}$ is the basal area of the cone $\left(\mathrm{m}^{2}\right)$. The resistance $\mathrm{R}$ (newton $\mathrm{m}^{-2}$, there is, pascal) is the force per unit of area that the soil offers against the dynamic penetration produced by one impact on the head of the penetrometer (Figure 1 ). The mass of the impact cylinder $(M)$ is $4.0 \mathrm{~kg}$ and the combined mass $(\mathrm{m})$ of the shaft, cone, and handleis $3.2 \mathrm{~kg}$. The falling distance ( $\mathrm{h}$ ) for mass $M$ is $40.0 \mathrm{~cm}$. The basal area of the cone is $1.2910^{-4}$ $\mathrm{m}^{2}$ based on the instrumentation standards adopted by the American Society of Agricultural Engineers (ASAE, 1976).

The equation to estimate $R$ (likea function of the distance of penetration caused by one impact) is provided by the balance of energy, considering the initial and final position of the system. The impact cylinder is raised to the initial position $\mathrm{h} \mathrm{cm}$ above the impact plate (Figure Ib). Upon falling, the cylinder's impact drives the penetrometer cone a distance of " $x$ " into the soil. Consequently, theimpact cylinder falls a distance of $h+x$. I mportant to this analysis is the fact that the impact also moves the penetrometer frame distance " $x$ " below its original position (Figure Ic). The maximum gravitational energy available for penetration of the cone is Mgh + Mgx + mgx where $g$ is the gravitational acceleration $\left(9.80 \mathrm{~m} \mathrm{~s}^{-2}\right)$. But a portion of this amount is lost by conversion into heat during the impact. The work done in advancing the penetrometer distance " $x$ " intothesoil for each singleblow is given by 


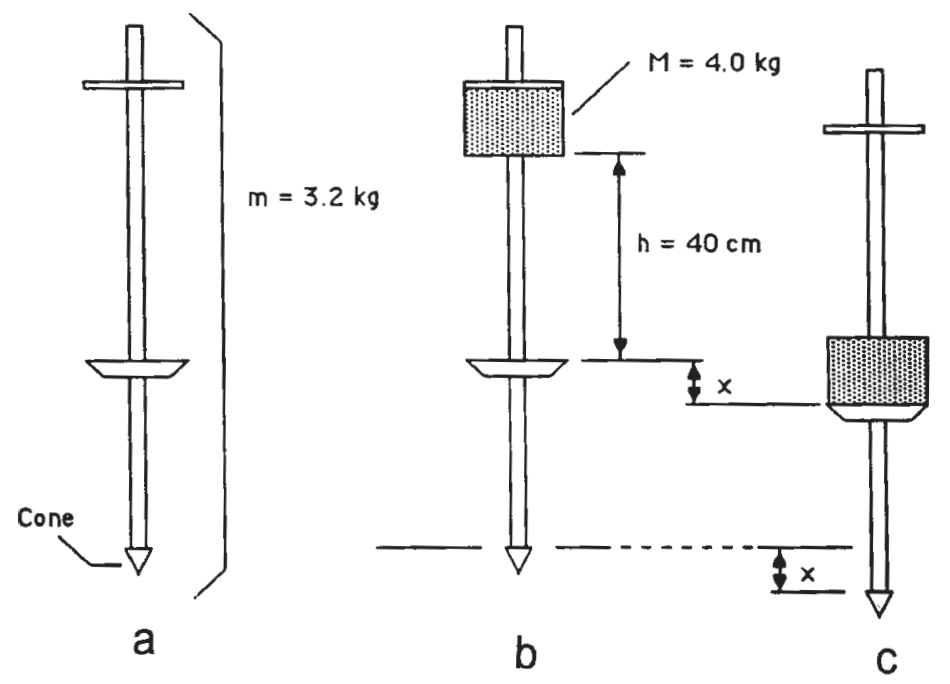

Figure 1. Stolf penetrometer: frame, $\mathrm{m}$, weighing $3.2 \mathrm{~kg} \mathrm{(a);} \mathrm{position} \mathrm{of} \mathrm{the} \mathrm{penetrometer} \mathrm{components}$ before dropping impact weight $M$ (b); location of the penetrometer frame $m$ and impact cylinder $M$ after impact (c). M moves the distance $h+x ; m$ moves the distance $x$.

$$
\mathrm{w}=\mathrm{F} \mathrm{x}=\mathrm{fMgh}+\mathrm{Mgx}+\mathrm{mgx}
$$

where $f$ is the coefficient of elasticity of the collision. For a totally elastic impact $f$ is equal to 1 . For a totally inelastic impact, Newton's third law states that the coefficient is

$$
f=M /(M+m)
$$

Although neither caseexists in practice, oneassumes that theimpact of the steel cylinder against the steel impact ledgeapproaches that of an inelastic collision. Substitution of [3] into [2] and solving for $F$ gives

$$
\mathrm{F}=[\mathrm{M}+\mathrm{m}] \mathrm{g}+[\mathrm{M} 2 /(\mathrm{M}+\mathrm{m})] \mathrm{gh} / \mathrm{X}
$$

Substitution of equation [4] into [1] and using the appropriatenumeric values for the penetrometer, one obtains the following expression for $\mathrm{R}$ (newton $/ \mathrm{m}^{2}$ or pascal)

$$
R=54710^{3}+675104 / x
$$

where $x$ is the penetration in $\mathrm{cm} / \mathrm{impact}$.

In practice, it is convenient to define $\mathrm{N}$ as the number of impacts required to drive the penetrometer some arbitrary depth into the soil. If it takes $\mathrm{N}$ impacts to drive the penetrometer $10 \mathrm{~cm}$ (1 dm) into the soil,

$$
x=10 / N
$$

Substituting [6] into equation [5] gives

$$
\mathrm{R}=54710^{3}+67510^{3} \mathrm{~N}
$$

Suppose 3 impacts caused $4 \mathrm{~cm}$ of penetration. Then, $\mathrm{N}=7.5 \mathrm{impacts} / \mathrm{dm}$. Applying equation (7), $\mathrm{R}=451510^{3}$ pascal. Depending on the range, it would be convenient to express the results in kilopascal ( $R=4515 \mathrm{kPa})$ or megapascal $(4.515 \mathrm{M} \mathrm{pa})$.

\section{MATE RIAL AND METHODS}

The capability of the impact penetrometer to measure mechanical impedance of a gravelly soil was evaluated in 1991 on selected plots of a longterm experiment that is evaluating various crop and soil management systems (King \& Buchanan(5)). The management systems were established in September 1985, Raleigh (35045'N, 780 42'W, elevation $75 \mathrm{~m})$, North Carolina, USA, on a Cecil gravelly loam (clayey, kaolinitic, thermic Typic Kanhapludults) on two percent sl ope with moderate to severeerosion. Therock content of the soil is quite variable with erratic pieces of large rock occurring occasionally. The volume percent of rocks in the matrix of the soil, excluding the erratics, in $10 \mathrm{~cm}$ increments, beginning at the soil surface and going down is: $2,3,2,<1,<1$ and $<1 \%$. The soil was formed from igneous rock with quartz intrusions. Over $95 \%$ of the rock present consists of quartz. Individual rocks are angular with the long axis less than twice the length of the shortest axis. Except for the erratics, which range in size from 5 to $15 \mathrm{~cm}$ in diameter, most particles were less than $1 \mathrm{~cm}$ effective diameter. In table 1 sand, silt and clay content are presented.

\footnotetext{
${ }^{(5)}$ King, L.D. \& Buchanan, M. Reduced chemical input cropping systems in the Southeast U nited States: I. Effect of rotations, green manures and fertilizer nitrogen on crop yields. Am. J . Alternative Agriculture (in press).
} 
Table 1. Textural class based on the USDA system for six $\mathbf{1 0} \mathrm{cm}$ thick layers

\begin{tabular}{ccccc}
\hline Depth & Sand & Silt & Clay & Class \\
\hline \multicolumn{1}{c}{$\mathrm{cm}$} & & $\%$ & & \\
$0-10$ & 49 & 25 & 26 & sandy clay loam \\
$10-20$ & 40 & 20 & 40 & clay \\
$20-30$ & 33 & 21 & 46 & clay \\
$30-40$ & 11 & 12 & 77 & clay \\
$40-50$ & 9 & 14 & 77 & clay \\
$50-60$ & 7 & 16 & 77 & clay \\
\hline
\end{tabular}

Penetrometer measurements weretaken on May 10, 1991 when the corn was less than $15 \mathrm{~cm}$ tall. The four systems studied, all of which were planted to corn, were:

Tilled: continuous, conventionally tilled corn (Zea mays): Chisel plowed $25 \mathrm{~cm}$ deep and disked prior to seeding.

No-till: continuous no-tillage corn: seeded directly behind coulters.

No-till/rotation: no-tillage with rotation of corn, wheat (Tritium vulgare L.), soybean (Glycine max L. (Merr.)): chronological rotation was wheat, soybean (1985-86); fallow, corn (1986-87); wheat, soybean (1987-88); fallow, corn (1988-89); wheat, soybean (1989-90); fallow, corn (1990-91).
Tilled/green manure: continuous, tilled corn with "Tibee" crimson clover (Trifolium incarnatum L.) as a winter green manure: clover seeded each fall and destroyed prior to corn planting by chisel plowing and disking.

Corn rows in each $8 \times 30 \mathrm{~m}$ plot were spaced $100 \mathrm{~cm}$ apart. Two-row tillage equipment pulled by a $2500 \mathrm{~kg}$ tractor was used for all plots, thus only alternate interrows were trafficked. The tilled/green manure system received two cultivations after planting. Corn plants were less than $15 \mathrm{~cm}$ high when penetrometer measurements were made.

A $4.0 \mathrm{~m}$ long transect, oriented perpendicular to the direction of the corn rows, was selected in each management system in one of theexperimental blocks. Soil resistance to a depth of $60 \mathrm{~cm}$ was measured with the Stolf penetrometer at 33 equally spaced points (12.5 cm apart) on the transect (Figure 2). Soil compaction by foot traffic during penetrometer measurements was prevented by walking on an elevated wooden plank parallel to the transect. Measurements were made by first holding the penetrometer vertical with the impact cylinder resting on the impact plateand letting the cone settle into the soil under the static load of the penetrometer. The penetration depth of the conewas recorded. While holding the penetrometer shaft in the vertical position, the impact cylinder was raised to a height of $40 \mathrm{~cm}$ (Figure Ib) and released repeatedly until the penetrometer cone penetrated an additional $5 \mathrm{~cm}$ (approximately) into the soil. The number of impacts and the final depth of penetration to the nearest $\mathrm{cm}$ were recorded. This procedure was

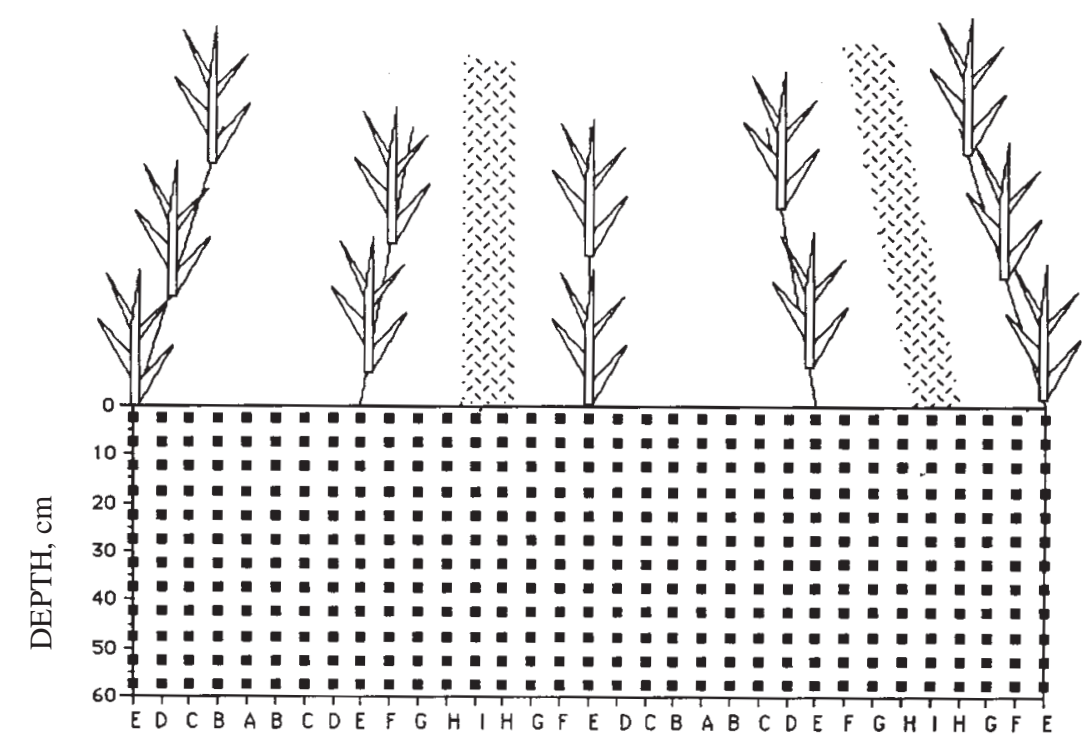

Figure 2. Sampling design: 33 horizontal points $12.5 \mathrm{~cm}$ apart and 12 depth increments each $5 \mathrm{~cm}$ long. Letters identify sampling points on the transect in relation to distance from the nearest corn row, and to the presence or absence of wheel compaction. 
repeated until the penetrometer cone was driven to the $60 \mathrm{~cm}$ depth. A total of $396 \mathrm{R}$ values were obtained for each transect. A computer program was employed to adjust $R$ values for exactly 5 to $5 \mathrm{~cm}$.

Soil water content in each row and in the centers of each trafficked and non-trafficked interrow (at positions $A, E$, and I in Figure 2) were determined in each plot using a time domain reflectometer. Wave guides 15, 30, 45 and $60 \mathrm{~cm}$ long were installed at each position. Soil volumetric water content $(\theta)$ for the 15 to $30 \mathrm{~cm}$ depth $\left(\theta_{15-30}\right)$, for example, was calculated by

$$
\theta_{15-30}=2 \theta_{0-30}-\theta_{0-15}
$$

where $\theta_{0-15}$ and $\theta_{0-30}$ are the average water contents in the 0 to 15 and 0 to $30 \mathrm{~cm}$ depths, respectively.

The computed $\mathrm{R}$ values for each transect were plotted using threedimensional graphics to visualize the horizontal and vertical variation. Positions along the transect were assigned identifiers A through I (Figure 2). Identifier E occurs in the corn row whereas, for example, I occurs in the center of trafficked interrows. In our analysis, one assumed that any factor acting on the soil to affect $R$ was symmetric with respect to the centers of each interrow. For example, the traffic pattern is assumed to be symmetric with respect to the center of the trafficked interrow; hence the amount of compaction and presumably $R$ would be identical at position $G$ on either side of I (Figure 2). A linear regression of $R$ against horizontal distance from the nearest row $(0$, $12.5,25,37.5$ or $50 \mathrm{~cm}$ ) was computed separately for the trafficked and non-trafficked interrows for each transect. All statistical computations were made using Statistical Analysis System software (SAS Institute, 1985). Levels of significance for the regression coefficients were determined according to Pimentel Gomes (1970).

\section{RESULTS AND DISCUSSION}

The penetrometer performed well during the 2day period required for two persons to complete data collection at all locations on the four transects. Even though small rocks (up to $15 \mathrm{~mm}$ in size) were present, the penetrometer was able to penetrate the soil without bending or breaking the penetrometer shaft. Soil dynamic resistance data were obtained to the $60 \mathrm{~cm}$ depth at all 33 position for all transects.

Soil resistance as a function of depth and position for the four transects are shown in figures 3a to 3d The mean soil resistance, computed by averaging all 33 measurements at a given depth for a given treatment, is plotted versus depth in figure 4.

Three features can be observed from figures $3 a$ to $3 d$ and figure 4 . First, there is a general increase in $\mathrm{R}$ with depth for each transect with the exception of the tilled/green manure system (Figures 3d and 4). The soil water content (Table 2) was near in situ fiel d capacity for all systems, except thetilled/green manure system for which some of the soil water stored in the 10 to 60 an depth had been depleted by crimson dover before it was permitted to dieand was incorporated.

A second feature, shown clearly for the tilled system (F igure 3a), is the pronounced effect of traffic wheeling as indicated by the higher soil resistance at shallow depths in the trafficked interrows. Chisel plowing prior to planting loosened the upper $20 \mathrm{~cm}$ of soil, while disking recompacted soil below the $10 \mathrm{~cm}$ depth. Wheel traffic during the planting operation markedly compacted the soil in the 0 to $15 \mathrm{~cm}$ depth, as evidenced by the large increase in soil resistanceat thecenter of the trafficked interrow.

Soil resistance for the no-till system (F igure $3 b$ ) was similar for both thetrafficked and non-trafficked interrows. This result was apparently surprising because no wheel traffic had occurred in the nontrafficked interrow, during the planting operation, for 4 years. It would be explained by the traffic of the machine harvest each year. In general, for notill, the minimum value of $\mathrm{R}$ occurred at the 0 to $5 \mathrm{~cm}$ depth in the row, the only location that was loosened by the coulter when the corn was planted and the roots start to grow.

The soil resistance pattern for the no-till/rotation system (Figure 3c) was similar to thosefor the tilled and no-tilled systems. However, the pattern for the tilled/green manure system differed from those of the other systems (Figure 3d). Soil resistance for the latter system was low in the 0 to $5 \mathrm{~cm}$ depth, which was loosened during the chisel plow and disk operations, but below this depth, $\mathrm{R}$ increased because the soil was dryer (Table 2). One hypothesis is that the crimson dover had utilized some of the stored available water prior to being destroyed.

The tilled and the tilled/green manure systems are similar in that they both are chisel plowed and disked prior to planting corn. Apparently, in the till/ green manure system, the partial incorporation of crimson clover during tillage prevents the wheeltrack compaction from developing to the extent found in the tilled system.

The third feature illustrated by the data in figures $3 a$ through $3 d$ is the presence of gravel or small rocks at randomly distributed locations in the subsoil. The effects of theserocks are most pronounced for the tilled and tilled/green manure systems, and are indicated by the abrupt increases in $\mathrm{R}$. The impact penetrometer was capable of penetrating, breaking, or pushing these rocks aside. A manuallyoperated penetrometer would have stopped when it encountered the rock. A hydraulically-operated penetrometer might have penetrated the rocks, but our experience has been that obstructions below the soil surface often result in bending the penetrometer shaft. 
a

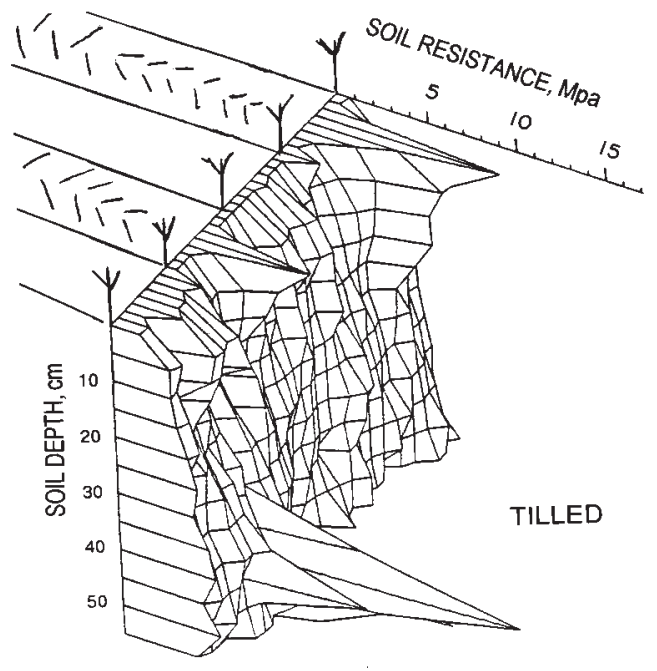

C

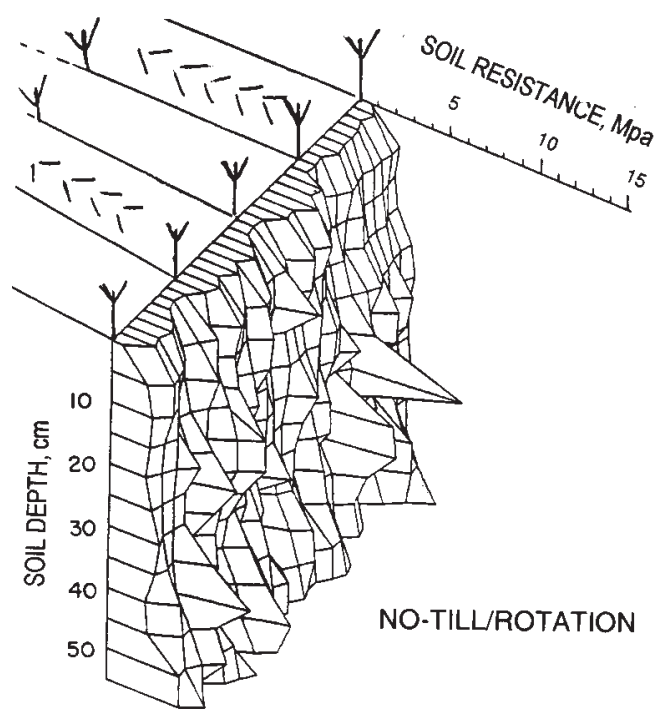

b

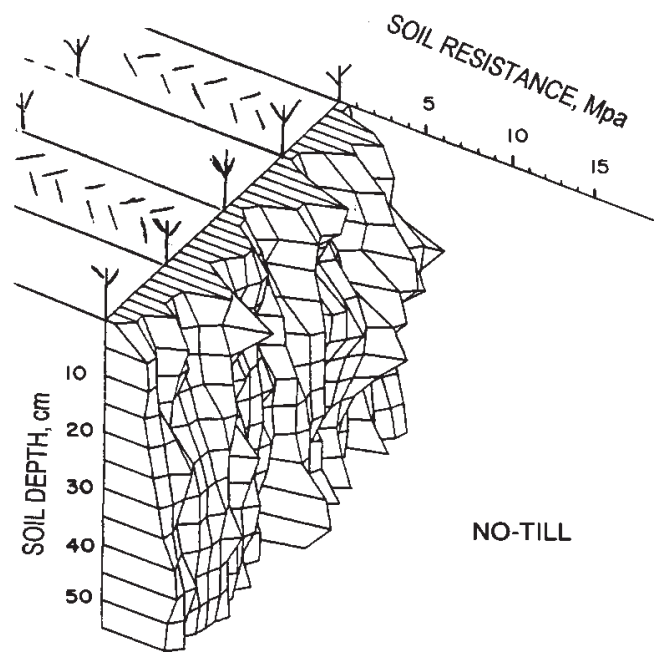

d

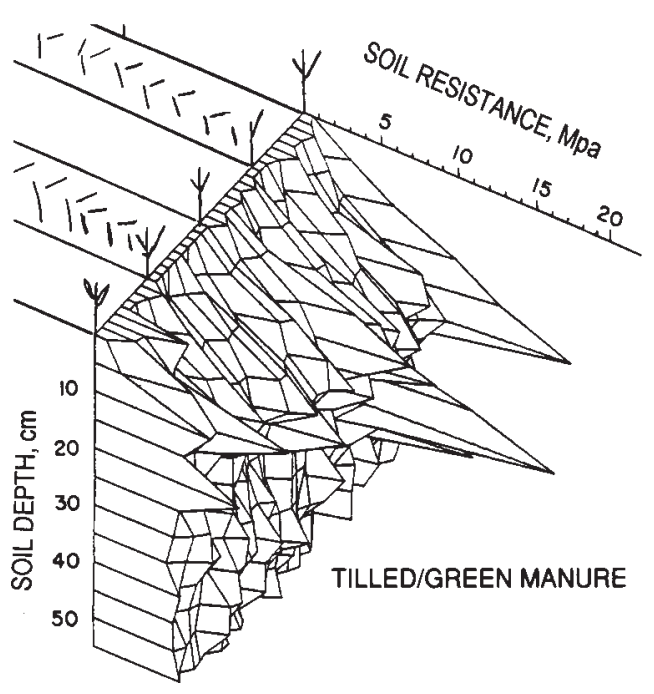

Figure 3. Spatial distribution of 396 measurements of dynamic soil resistance in a vertical section crossing four interrows of the: tilled system (a), no-till system (b), no-till rotation system (c), and tilled/green manure system (d).

Because there appeared to be a cyclical change in dynamic resistance along the transect (for example, observethe variation in $\mathrm{R}$ at the soil surface in figures 3a through 3d), one devel oped regression equations for $\mathrm{R}$ against horizontal distance from the corn row to the middle of the interrow for both the trafficked and non-trafficked interrows at all soil depths. The only consistent trend was for $\mathrm{R}$ to increase with distance from the corn row in the trafficked interrows for thetilled system (Figure 5). According to the same figure, the maximum increment per unit of horizontal distance (slope) was
$102 \mathrm{kPa} \mathrm{cm}^{-1}$. Regression models for this management system were significant ( $P=0.1$ or 0.05 level) at each sampling increment to a depth of $40 \mathrm{~cm}$; the correlation coefficients $(r)$ ranged from 0.83 to 0.95 .

It was concluded that the impact penetrometer effectively measures dynamic resistance in soils having high soil strength. Although the penetrometer can be used by one person, it is more efficient and less tiring when two persons work together, especially when a large number of measurements are required. It is particularly tiring to repeatedly lift the $4 \mathrm{~kg}$ impact cylinder. 


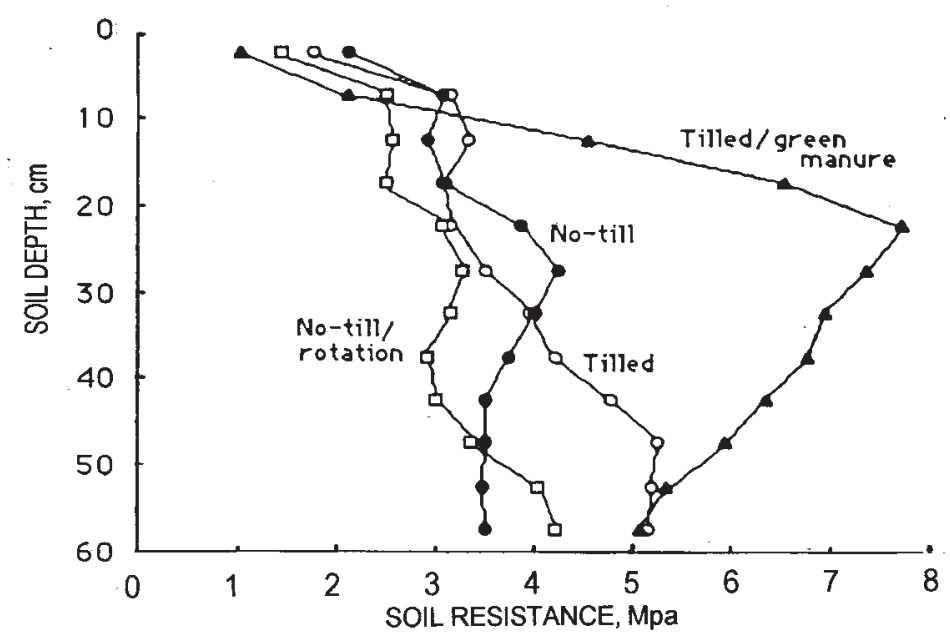

Figure 4. Effect of crop management systems and depth on soil resistance. Each value is the mean of 33 measurements.

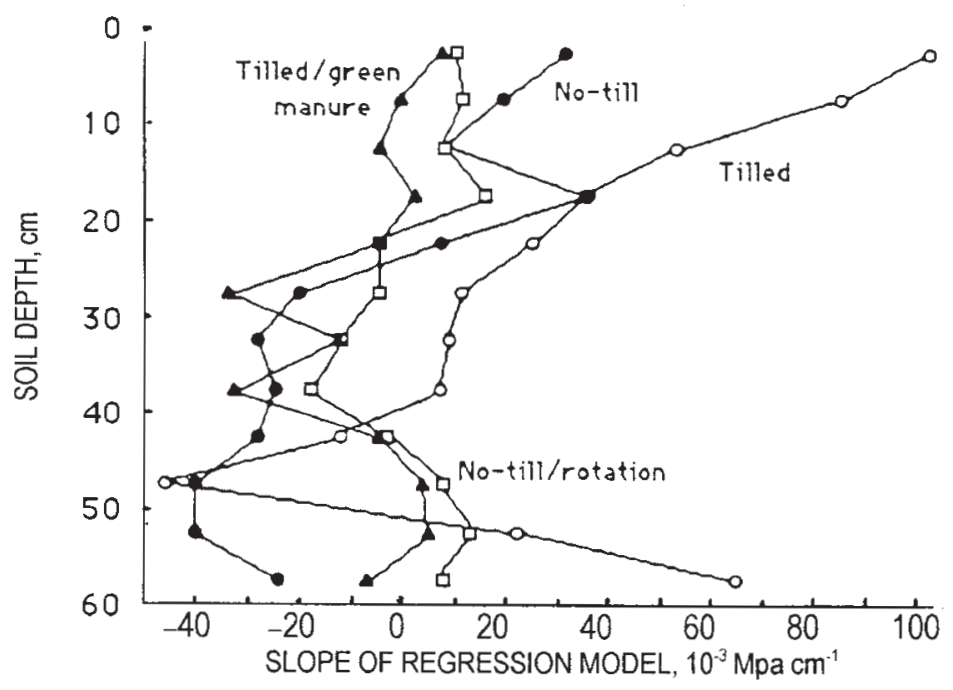

Figure 5. Slope of models for dynamic resistance in the trafficked interrow regressed on distance from the corn row.

Table 2. Soil water content distribution at time of penetrometer measurements

\begin{tabular}{ccc}
\hline \multirow{2}{*}{ Depth } & \multicolumn{2}{c}{ Mean water content } \\
\cline { 2 - 3 } & Treatments 1, 2, 3 & Treatment 4 \\
\hline $\mathrm{cm}$ & \multicolumn{2}{c}{$\mathrm{m}^{3} \mathrm{~m}^{-3}$} \\
$0-15$ & 0.26 & 0.25 \\
$15-30$ & 0.36 & 0.31 \\
$30-45$ & 0.37 & 0.34 \\
$45-60$ & 0.47 & 0.37 \\
\hline
\end{tabular}

\section{LITERATURE CITED}

AMERICAN SOCIETY OF AGRICULTURAL ENGINEERS-ASAE. Soil cone penetrometer. St. J oseph, ASAE Agricultural Engineers Yearbook, 1976. p.368-369 (ASAE Rec., 313:1).

CASSEL, D.K. Spatial and temporal variability of soil physical properties foll lowing tillage of N orfolk loamy sand. Soil Sci. Soc. Am. J ., 47:196-201,1983.

CASSEL, D.K.; BOWEN, H.D. \& NELSON, L.A. An evaluation of mechanical impedance for three tillage treatments on Norfolk sandy loam. Soil Sci. Soc. Am. J ., 42:116-120, 1978.

CULLEY, J.L.B.; LARSON, W.E. \& RANDALL, G.W. Physical properties of a Typic Haplaquoll under conventional and no-tillage. Soil Sci. Soc. Am. J., 51:1587-1592, 1987. 
NESMITH, D.S.; HARGROVE, W.L.; RADCLIFFE, E.W. \& ARIOGLU, H.H.Tillage and residue management effects of an Ultisol and double-cropped soybean production. Agron. J., 79:570-576, 1987.

PIMENTEL GOMES, F. Curso de estatistica experimental. 4.ed. São Paulo, Nobel, 1970. 430p.

SAS INSTITUTE. User's guide: Statistics, version 5th ed. Cary, North Carolina, 1985.

STOLF, R.; FERNANDES, J . \& FURLANI, V.L. Penetrômetro de Impacto modelo IAA/PIanalsucar. Stolf; recomendação para seu uso. STAB-Açúcar, Álcool e Subprodutos, 1:18-23, 1983.
STOLF, R. \& FAGANELLO, B.F. Utilização do penetrômetro de impacto modelo IAA/PIanalsucar-Stolf na recomendação do preparo de solo na usina Nossa Senhora Aparecida (Pontal-SP). STAB - Açúcar, Álcool e Subprodutos, 1:11-22, 1983.

STOLF, R. Theory and test of formulas for transforming impact penetrometer data in soil resistance. R. Bras. Ci. Solo, 15:229-235, 1991.

VEPRASKAS, M.J. A method to estimate the probability that subsoiling will increase crop yields. Soil Sci. Soc. Am. J ., 52:229-232, 1988. 